\title{
Effects of Fall Applications of Chemical Defoliants, Urea, and Gibberellic Acid on Defoliation in the Fall and Performance of Hydrangeas During Forcing
}

\author{
Guihong Bi ${ }^{1}$ \\ Truck Crops Branch Experiment Station, Mississippi State University, 2024 \\ Experiment Station Road, P.O. Box 231, Crystal Springs, MS 39059
}

\section{Carolyn F. Scagel}

U.S. Department of Agriculture, Agricultural Research Service, Horticultural Crops Research Unit, 3420 NW Orchard Avenue, Corvallis, OR 97330

Additional index words. Hydrangea macrophylla 'Merritt's Supreme', Def 6, tributyl phosphorotrithioate, CuEDTA, Florel

\begin{abstract}
In two separate experiments, Hydrangea macrophylla (Thunb.) Ser. 'Merritt's Supreme' plants were used to study the effects of foliar sprays of Def 6 (tributyl phosphorotrithioate, 2500, 5000, 7500, and $\left.10,000 \mathrm{mg} \cdot \mathrm{L}^{-1}\right)$, gibberellic acid (GA, 50 $\left.\mathrm{mg} \cdot \mathrm{L}^{-1}\right)$, copper-EDTA $($ CuEDTA, $0.5 \%$ and $1.0 \%)$, Florel $\left(2000 \mathrm{mg} \cdot \mathrm{L}^{-1}\right)$, and urea $(3 \%)$ on defoliation in the fall and growth and flowering performance during forcing. Compared with controls (plants sprayed with water only), spraying plants with urea or GA alone had no influence on defoliation or plant performance during forcing, and spraying plants with Florel alone had no influence on defoliation but decreased total flower dry weight during forcing. Combining urea with Florel sprays decreased the adverse effects of Florel on plant quality and combining GA with Florel improved defoliation. Increasing concentrations of Def 6 and CuEDTA increased defoliation. Compared with controls, plants sprayed with CuEDTA exhibited more defoliation, showed bud and leaf necrosis, and produced lower flower dry weight during forcing. Combining urea with CuEDTA sprays decreased the adverse effects of CuEDTA on plant quality. Compared with controls, spraying plants with Def 6 increased defoliation, caused no visible damage to plants, and had no adverse effects on plant quality during forcing. Adding urea to sprays containing Def 6 decreased or had no influence on the efficiency of defoliation and increased total flower dry weight during forcing compared with Def 6 alone. Adding GA to sprays containing lower concentrations of Def $6\left(2500\right.$ and $\left.5000 \mathrm{mg} \cdot \mathrm{L}^{-1}\right)$ increased the efficiency of defoliation without adversely influencing plant quality.
\end{abstract}

During production of florists' hydrangea, defoliation before cold storage is required for prevention of diseases such as botrytis bud rot (Bailey, 1989). Many hydrangea growers

Received for publication 16 June 2009. Accepted for publication 21 July 2009.

We thank Clay Cheroni, Peter Hudson, and Melvin Townsend for their technical assistance; Mark Terkanian from Natchez Trace Greenhouse for his contribution to the on-farm study; Oregon Hydrangea Company for plant material; and Bayer CropScience for the chemical Def 6 .

Contribution of the Mississippi Agricultural and Forestry Experiment Station Journal article no. $\mathrm{J}-11614$.

Mention of a trademark, proprietary product, or vendor does not constitute a guarantee or warranty of the product by the U.S. Dept. of Agriculture and does not imply its approval to the exclusion of other products or vendors that also may be suitable.

${ }^{1}$ To whom reprint requests should be addressed; e-mailgb250@msstate.edu. been found to be able to enhance chemical [BD and TPTA (tributyl phosphorotrithioate)] defoliation of hydrangeas (Bailey, 1990).

During natural leaf senescence, deciduous plants can mobilize nutrients, including nitrogen $(\mathrm{N})$, from leaves into storage tissues (Titus and Kang, 1982). Stored $\mathrm{N}$ is important for the initial growth of deciduous plants in spring, and there is a positive relationship between the amount of stored $\mathrm{N}$ and spring growth in many species (Cheng and Fuchigami, 2002; Cheng and Xia, 2004; Taylor, 1967; Taylor and May, 1967). The N mobilized from senescing leaves makes an important contribution to whole plant $\mathrm{N}$ economy (Chapin and Kedrowski, 1983; Taylor and May, 1967). For example, in apple, N mobilized during leaf senescence constitutes $\approx 25 \%$ of the total plant $\mathrm{N}$ (Cheng et al., 2002). Manual or chemical defoliation removes green leaves from plants before any significant $\mathrm{N}$ mobilization occurs. In Hydrangea macrophylla 'Merritt's Supreme', $\approx 50 \%$ of total plant $\mathrm{N}$ was in leaves in early fall (Bi et al., 2008). Early defoliation could potentially decrease $\mathrm{N}$ storage and result in poor growth and flower development during forcing.

Foliar sprays of urea in the fall after terminal bud set can increase reserve $\mathrm{N}$ in deciduous plants without stimulating new growth late in the season (Cheng et al., 2002; Sanchez et al., 1990; Tagliavini et al., 1998). Increased $\mathrm{N}$ from urea sprays can compensate for the $\mathrm{N}$ lost from early defoliation and improve plant growth and development during the next growing season (Bi et al., 2005; Guak et al., 2001). Spraying florists' hydrangea with urea before manual defoliation has the potential to improve growth and increase the number of flowers and flower size during forcing (Bi et al., 2008). At present, there is no available information on whether spraying hydrangea with urea ameliorates the effects of chemical defoliants on growth and flowering performance during forcing.

This article presents the results of two studies assessing the effects of foliar sprays with chemical defoliants and urea on defoliation in the fall and plant performance during forcing in florists' hydrangea. Our objective was to determine if the combination of urea with defoliant applications promotes early defoliation and maintains or improves growth and flowering performance during forcing.

\section{Materials and Methods} dures for some chemicals such as Vapam (sodium N-methyldithiocarbamate) and ethylene require an air-tight storage unit. Some chemicals such as 2-butyne-1,4-diol (BD) are effective defoliants at high concentrations but are poisonous to humans and require special safety regulations for application. The influence of only a few combinations of chemicals on defoliation of hydrangea has been evaluated. Gibberellic acid $\left(\mathrm{GA}_{3}\right)$ has
Expt. 1. A study was conducted at the Truck Crops Branch Experiment Station in Crystal Springs, MS (lat. 31 ${ }^{\circ} 59^{\prime} \mathrm{N}$, long. $\left.90^{\circ} 21^{\prime} \mathrm{W}\right)$. Rooted Hydrangea macrophylla (Thunb.) Ser. 'Merritt's Supreme' cuttings were potted into Elite/Ultra Azalea pots $(17.8 \mathrm{~cm}$ o.d., $12.7 \mathrm{~cm}$ height, $2100 \mathrm{~cm}^{3}$ volume; ITML Horticultural Products, Inc., Brantford, Ontario, Canada) containing Sun Gro 
\#4 (Sun Gro Horticulture, Bellevue, WA) in late May 2006. Each pot contained two cuttings that were pinched (leaving two nodes per shoot) in early June. Starting in early June, plants were fertigated two times per week with $200 \mathrm{mg} \cdot \mathrm{L}^{-1} \mathrm{~N}(20 \mathrm{~N}-4.4 \mathrm{P}-$ 16.6K; TotalGro 20-10-20; SDT Industries, Inc., Winnsboro, LA) for 6 weeks followed by $150 \mathrm{mg} \cdot \mathrm{L}^{-1} \mathrm{~N}$ for the next 4 weeks and $100 \mathrm{mg} \cdot \mathrm{L}^{-1} \mathrm{~N}$ for another 4 weeks. Plants were grown outdoors under shadecloth $(40 \%$ shade) and drip-irrigated as needed throughout the growing season. Plants were sprayed twice in July and once in August with 5000 $\mathrm{mg} \cdot \mathrm{L}^{-1}$ daminozide [B-9, butanedioic acid mono (2,2-dimethylhydrazide); Crompton Manufacturing Company, Inc., Middlebury, $\mathrm{CT}]$ to control plant height.

On 31 Oct. 2006, plants were selected for uniformity and eight plants were randomly assigned to each of 19 treatments (Table 1). Def (Def 6; Bayer CropScience, Research Triangle Park, NC) contains $6 \mathrm{lb}$ S,S,Stributyl phosphorotrithioate per gallon. Florel (Southern Agricultural Insecticides, Inc., Hendersonville, NC) contains 3.9\% ethephon. ProGibb T\&O (Valent U.S.A. Corporation, Walnut Creek, CA) contains 4.0\% GA. Applications were made using a backpack sprayer and plants in the control treatment were sprayed with water only. Plants were sprayed to the point of runoff on leaves to assure complete spray coverage of the foliage for best results. Leaf color was observed visually after spray applications and any color change was recorded. Defoliation on each plant was recorded $7 \mathrm{~d}$ and $14 \mathrm{~d}$ after treatment. Defoliation was determined by estimating the

Table 1. Chemical combinations used in foliar sprays in two experiments assessing the effects of different chemical combinations on defoliation and plant growth and flowering performance of Hydrangea macrophylla 'Merritt's Supreme' during forcing.

\begin{tabular}{|c|c|c|c|c|c|c|}
\hline \multirow[b]{2}{*}{ Expt. $^{\mathrm{z}}$} & \multirow[b]{2}{*}{ Treatment $^{\mathrm{x}}$} & \multicolumn{5}{|c|}{ Chemicals $^{y}$} \\
\hline & & $\overline{\text { Def } 6\left(\mathrm{mg} \cdot \mathrm{L}^{-1}\right)}$ & Florel & CuEDTA (\%) & Urea & $\overline{\text { GA }}$ \\
\hline 1,2 & Control & - & - & - & - & - \\
\hline 1,2 & $\mathrm{U}$ & - & - & - & + & - \\
\hline 1,2 & GA & - & - & - & - & + \\
\hline 1 & $0.5 \mathrm{Cu}$ & - & - & 0.5 & - & - \\
\hline 1 & $1.0 \mathrm{Cu}$ & - & - & 1.0 & - & - \\
\hline 1 & $0.5 \mathrm{Cu}+\mathrm{U}$ & - & - & 0.5 & + & - \\
\hline 1 & $1.0 \mathrm{Cu}+\mathrm{U}$ & - & - & 1.0 & + & - \\
\hline 1 & Def 2500 & 2,500 & - & - & - & - \\
\hline 1,2 & Def5000 & 5,000 & - & - & - & - \\
\hline 1,2 & Def7500 & 7,500 & - & - & - & - \\
\hline 2 & Def10000 & 10,000 & - & - & - & - \\
\hline 1,2 & Def $2500+$ GA & 2,500 & - & - & - & + \\
\hline 1,2 & Def5000 + GA & 5,000 & - & - & - & + \\
\hline 1 & Def $7500+$ GA & 7,500 & - & - & - & + \\
\hline 1 & Def $2500+U$ & 2,500 & - & - & + & - \\
\hline 1,2 & Def5000+U & 5,000 & - & - & + & - \\
\hline 1,2 & Def $7500+U$ & 7,500 & - & - & + & - \\
\hline 2 & Def $2500+\mathrm{U}+\mathrm{GA}$ & 2,500 & - & - & + & + \\
\hline 2 & Def5000 + U+GA & 5,000 & - & - & + & + \\
\hline 1 & $\mathrm{~F}$ & - & + & - & - & - \\
\hline 1 & $\mathrm{~F}+\mathrm{U}$ & - & + & - & + & - \\
\hline 1 & $\mathrm{~F}+\mathrm{GA}$ & - & + & - & - & + \\
\hline
\end{tabular}

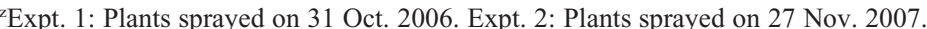

${ }^{\mathrm{y}}$ Def $6=\mathrm{S}, \mathrm{S}, \mathrm{S}-\mathrm{tributyl}$ phosphorotrithioate at $0(-)$ and $2500,5000,7500$, and $10,000 \mathrm{mg} \cdot \mathrm{L}^{-1}$; Florel $=$ ethephon $\left(2\right.$-chloroethylphosphonic acid) at $0(-)$ and $2000 \mathrm{mg} \cdot \mathrm{L}^{-1}(+)$; CuEDTA $=$ Copper EDTA at $0(-)$ and $0.5 \%$ and $1.0 \%$; urea $=0(-)$ and $3 \%$ urea $(+)$; GA $=0(-)$ and $50 \mathrm{mg} \cdot \mathrm{L}^{-1}$ gibberellic acid from ProGibb T\&O (+).

${ }^{\mathrm{x}} \mathrm{U}=$ urea; $\mathrm{Cu}=$ CuEDTA; Def $=$ Def $6 ; \mathrm{F}=$ Florel. forced as described for Expt. 1. In late Apr. 2008, plant heights were recorded.

Experimental design and statistical analyses. Treatments were set up in a completely randomized design with each experimental unit (pot) replicated eight times for Expt. 1 and 15 times for Expt. 2. Data were analyzed by one-way analysis of variance. The effects of Def concentration on response variables were evaluated using a priori polynomial contrasts based on the concentrations of Def in sprays. Specific a priori contrasts were used to compare means between control and other treatments and to assess the effects of copper concentration and addition of urea and GA to sprays. Defoliation data were arcsine-transformed before analysis and back-transformed for data presentation. All analyses were performed using Statistica ${ }^{\circledR}$ (Statsoft, Inc., Tulsa, OK).

\section{Results and Discussion}

The chemical Def 6 is an effective defoliant for use with florists' hydrangeas. At the concentrations tested $(2500,5000,7500$, and $\left.10,000 \mathrm{mg} \cdot \mathrm{L}^{-1}\right)$, we observed no visible injury to plants (data not shown), and plant quality during forcing (e.g., flower dry weight and plant height) was not adversely influenced by sprays with Def 6 during the previous fall (control versus Def 6; Tables 2 and 3). Although spraying plants with 10,000 $\mathrm{mg} \cdot \mathrm{L}^{-1}$ Def 6 significantly reduced plant height compared with controls, the reduction in height is not considered a negative influence on plant performance because hydrangeas normally require height control during forcing. In both Expt. 1 and Expt. 2, spraying plants with Def 6 promoted earlier defoliation compared with control plants and increasing the concentration of Def 6 in the spray improved defoliation (Def 6 linear contrasts; Tables 2 and 3). Seven days after spraying plants with Def 6 at 7500 and 10,000 $\mathrm{mg} \cdot \mathrm{L}^{-1}$, plants were $90 \%$ to $98 \%$ defoliated. Similarly, Bailey (1990) reported spraying hydrangeas with 7500 to $15,000 \mathrm{mg} \cdot \mathrm{L}^{-1}$ tributyl phosphorotrithioate (TPTA) resulted in $93 \%$ to $100 \%$ defoliation after $7 \mathrm{~d}$ and defoliation increased linearly with increasing concentration of TPTA from 2500 up to $7500 \mathrm{mg} \cdot \mathrm{L}^{-1}$.

Our results indicate copper-EDTA (CuEDTA) can also promote early defoliation of florists' hydrangeas (control versus copper; Table 2) and $1.0 \%$ CuEDTA is more effective than $0.5 \%$ CuEDTA on promoting early defoliation (Table 2); however, at the concentrations tested $(0.5 \%$ and $1.0 \%)$, we observed some necrosis on leaves and buds after spraying (data not shown) and 1.0\% CuEDTA had a negative effect on plant quality during forcing (Table 2). CuEDTA has been used as a defoliant for nursery plants (Bi et al., 2005; Guak et al., 2001; Knight, 1983; Larsen and Fritts, 1986). Using apple and cherry rootstocks, substantial defoliation was achieved by spraying trees with $2.1 \%$ CuEDTA with little or no damage to plants (Knight, 1983). Using apple, cherry, and pear 
Table 2. Defoliation in the fall of 2006 and plant height and flower dry weight of Hydrangea macrophylla 'Merritt's Supreme' in the spring of 2007 after being sprayed with different combinations of chemical defoliants, urea, and GA in the fall of 2006.

\begin{tabular}{|c|c|c|c|c|}
\hline \multirow[b]{2}{*}{ Treatment $^{2}$} & \multicolumn{2}{|c|}{ Defoliation (\%) } & \multirow[b]{2}{*}{ Flower dry wt (g) } & \multirow[b]{2}{*}{ Plant ht $(\mathrm{cm})$} \\
\hline & $7 \mathrm{~d}$ & $14 \mathrm{~d}$ & & \\
\hline Control & 0 & 0 & 25.5 & 36.6 \\
\hline $\mathrm{U}$ & 0 & 0 & 27.0 & 37.7 \\
\hline GA & 0 & 0 & 24.7 & 34.5 \\
\hline $0.5 \mathrm{Cu}$ & $27 * y$ & $38 *$ & 24.1 & 36.0 \\
\hline $0.5 \mathrm{Cu}+\mathrm{U}$ & 8 & 14 & 25.6 & 38.3 \\
\hline $1.0 \mathrm{Cu}$ & $60 * *$ & $72 * *$ & $17.8^{* *}$ & 33.3 \\
\hline $1.0 \mathrm{Cu}+\mathrm{U}$ & $43 * *$ & $60 * *$ & 24.3 & 33.5 \\
\hline Def 2500 & $63 * *$ & $72 * *$ & 22.7 & 35.5 \\
\hline Def $2500+U$ & $40 * *$ & $56 * *$ & 27.2 & 35.6 \\
\hline Def $2500+$ GA & $82 * * *$ & $90 * * *$ & 25.0 & 36.6 \\
\hline Def 5000 & $82 * * *$ & $91 * * *$ & 23.0 & 35.7 \\
\hline Def $5000+U$ & $66 * *$ & $80 * * *$ & 27.6 & 41.7 \\
\hline Def $5000+$ GA & $97 * * *$ & $100^{* * *}$ & 21.8 & $30.9 * *$ \\
\hline Def7500 & $97 * * *$ & $100 * * *$ & 22.6 & 34.5 \\
\hline Def $7500+U$ & $90 * * *$ & $98 * * *$ & 26.9 & 33.8 \\
\hline Def $7500+$ GA & $100 * * *$ & $100 * * *$ & 24.9 & 38.4 \\
\hline $\mathrm{F}$ & 8 & 10 & $19.1^{* *}$ & 35.5 \\
\hline $\mathrm{F}+\mathrm{U}$ & 5 & 5 & 25.0 & 32.3 \\
\hline $\mathrm{F}+\mathrm{GA}$ & $35^{* *}$ & $50 * *$ & $21.4^{*}$ & $30.0^{* *}$ \\
\hline \multicolumn{5}{|c|}{ Def concentration responses ${ }^{x}$} \\
\hline Def & $L$ & $L$ & NS & NS \\
\hline Def $+U$ & $L$ & $L$ & NS & NS \\
\hline Def + GA & $L$ & $L$ & NS & NS \\
\hline \multicolumn{5}{|c|}{ Cu comparisons ${ }^{x}$} \\
\hline $\mathrm{Cu}: 0.5$ versus $1.0 \mathrm{Cu}$ & $* *$ & $* *$ & $* * *$ & $*$ \\
\hline $\mathrm{Cu}+\mathrm{U}: 0.5$ versus $1.0 \mathrm{Cu}$ & $* *$ & $* *$ & $*$ & $*$ \\
\hline \multicolumn{5}{|c|}{ Urea comparisons $^{x}$} \\
\hline Def versus Def $+U$ & $* *$ & $* *$ & $* * *$ & NS \\
\hline $\mathrm{Cu}$ versus $\mathrm{Cu}+\mathrm{U}$ & $* *$ & $* *$ & $* * *$ & NS \\
\hline $\mathrm{F}$ versus $\mathrm{F}+\mathrm{U}$ & NS & NS & $* * *$ & NS \\
\hline \multicolumn{5}{|c|}{ GA comparisons ${ }^{x}$} \\
\hline Def 2500: Def versus Def + GA & ** & $* *$ & NS & NS \\
\hline Def 5000: Def versus Def + GA & ** & ** & NS & NS \\
\hline Def 7500: Def versus Def + GA & NS & NS & NS & NS \\
\hline $\mathrm{F}$ versus $\mathrm{F}+\mathrm{GA}$ & $* *$ & ** & NS & ** \\
\hline
\end{tabular}

${ }^{\mathrm{z}}$ Spray treatment combinations as outlined in Table 1 . Control $=$ sprayed with water; $\mathrm{U}=3 \%$ urea; $\mathrm{GA}=$ $50 \mathrm{mg} \cdot \mathrm{L}^{-1}$ gibberellic acid from ProGibb T\&O; $\mathrm{Cu}=\mathrm{CuEDTA}$ at $0.5 \%(0.5 \mathrm{Cu})$ and $1.0 \%(1.0 \mathrm{Cu})$; Def $=2500\left(\right.$ Def2500), 5000 (Def5000), and $7500\left(\right.$ Def7500) $\mathrm{mg} \cdot \mathrm{L}^{-1}$ Def 6; F $=2000 \mathrm{mg} \cdot \mathrm{L}^{-1}$ Florel.

${ }^{\mathrm{y}} \mathrm{Means}$ within a column denoted by asterisk(s) are significantly different from control plants $P<0.05(*)$, $P<0.01(* *)$, and $P<0.001(* * *)(\mathrm{n}=8)$.

${ }^{\mathrm{x}}$ Def concentration responses: significant $(P<0.05)$ linear $(L)$ a priori polynomial contrasts based on the concentrations of Def in sprays. Cu comparisons, urea comparisons, and GA comparisons: specific a priori contrasts to assess the effects of $\mathrm{Cu}$ concentrations; adding urea to sprays containing Def, $\mathrm{Cu}$, or F; and adding GA to sprays containing Def or $\mathrm{F}$ at $P<0.05\left(^{*}\right), P<0.01(* *)$, and $P<0.001(* * *)$; NS $=$ nonsignificant $(P>0.05)$.

trees, Larsen and Fritts (1986) obtained 80\% or more defoliation $14 \mathrm{~d}$ after spraying plants with concentrations of $0.5 \%$ CuEDTA or greater; however, they also observed some bud and bark damage in trees sprayed with CuEDTA. Our results suggest CuEDTA at the concentrations tested is a less effective defoliant for florists' hydrangea than Def 6 (5000 $\mathrm{mg} \cdot \mathrm{L}^{-1}$ and above) and may also potentially have adverse effects on plant quality during forcing (Table 2).

In general, combining 3\% urea with the defoliants Def 6 or CuEDTA decreased or had no influence on defoliation of florists' hydrangea compared with plants sprayed only with defoliants (Def versus Def $+U$ and $\mathrm{Cu}$ versus $\mathrm{Cu}+\mathrm{U}$; Tables 2 and 3). In Expt. 1, adding urea to the Def 6 or CuEDTA sprays decreased the defoliation effect of the defoliants and generally improved flower dry plant quality of florists' hydrangea during forcing. Similarly, combining urea with defoliant sprays on young apple nursery trees can improve plant $\mathrm{N}$ reserves and result in better tree growth during establishment the next spring (Guak et al., 2001). This suggests urea sprays may compensate for the $\mathrm{N}$ lost as a result of early defoliation, and combining urea with appropriate defoliant sprays may be considered a strategy to promote earlier defoliation without reducing plant quality, especially for plants with low $\mathrm{N}$ status. This theory is also supported by our results using urea with CuEDTA on florists' hydrangea. Adding urea into sprays containing CuEDTA may have decreased the efficiency of defoliation; however, our results suggest the effects of urea mitigated some of the negative effects of CuEDTA, mentioned previously, on plant quality during forcing. This type of compensatory response of adding urea to CuEDTA sprays is similar to the effects of combing urea and CuEDTA in sprays to defoliate bareroot apple and almond nursery trees (Bi et al., 2005; Guak et al., 2001). If cost or availability issues cause growers to choose CuEDTA over Def 6 as a defoliant for use with florists' hydrangeas, then adding urea to CuEDTA sprays may decrease the adverse effect of CuEDTA on plant quality during forcing.

The results from Expt. 1 suggest Florel (ethephon) is not an effective defoliant for use with florists' hydrangeas. At the concentration tested $\left(2000 \mathrm{mg} \cdot \mathrm{L}^{-1}\right)$, spraying plants with Florel in late October did not promote early defoliation and, although we observed no visible injury to plants (data not shown), plant quality during forcing (e.g., flower dry weight) was decreased by sprays with Florel during the previous fall (control versus Florel; Table 2). Bailey (1990) also reported ethephon did not promote early defoliation of hydrangea. Adding urea to Florel sprays had no influence on the defoliation effects of Florel but mitigated some of the negative effects of Florel on plant quality during forcing ( $\mathrm{F}$ versus $\mathrm{F}+\mathrm{U}$; Table 2 ).

Adding GA $\left(50 \mathrm{mg} \cdot \mathrm{L}^{-1}\right)$ to sprays containing Def $6\left(2500\right.$ and $\left.5000 \mathrm{mg} \cdot \mathrm{L}^{-1}\right)$ and Florel increased the efficiency of defoliation of florists' hydrangea (Def versus Def + GA and F versus F+GA; Tables 2 and 3). Bailey (1990) also reported combining GA with TPTA at lower concentrations $\left(2500\right.$ and $\left.5000 \mathrm{mg} \cdot \mathrm{L}^{-1}\right)$ increased defoliation of hydrangea over that obtained from sprays containing only TPTA. Interestingly, using sprays of only GA on florists' hydrangea had no influence on either defoliation in the fall or performance during forcing and the synergistic effects of combining GA with Def 6 at lower concentrations or Florel on defoliation did not result in any negative influence on plant performance during forcing compared with Def 6 or Florel alone, although plants were shorter when treated with a combination of Florel and GA compared with Florel alone. This suggests the influence of GA on defoliation may not influence factors related to plant performance during the next growing cycle. 
Table 3. Defoliation in the fall of 2007 and plant height of Hydrangea macrophylla 'Merritt's Supreme' in the spring of 2008 after being sprayed with different combinations of chemical defoliant, urea, and GA in the fall of 2007.

\begin{tabular}{|c|c|c|}
\hline Treatment $^{z}$ & Defoliation (\%) $7 \mathrm{~d}$ & Plant ht $(\mathrm{cm})$ \\
\hline Control & 5 & 40.9 \\
\hline $\mathrm{U}$ & 0 & 40.5 \\
\hline GA & 5 & 39.0 \\
\hline Def $2500+$ GA & $75 * * \mathrm{y}$ & 39.8 \\
\hline Def $2500+U+G A$ & $55^{*}$ & 40.7 \\
\hline Def5000 & $77 * *$ & 36.5 \\
\hline Def5000+U & $85 * * *$ & 42.3 \\
\hline Def5000 + GA & $93 * * *$ & 37.6 \\
\hline Def5000 + U + GA & $89 * * *$ & 38.9 \\
\hline Def7500 & $90 * * *$ & 38.3 \\
\hline Def $7500+U$ & $92 * * *$ & 39.3 \\
\hline Def10000 & $98 * * *$ & $35.4 *$ \\
\hline \multicolumn{3}{|c|}{ Def concentration responses ${ }^{x}$} \\
\hline Def & $L$ & NS \\
\hline Def $+U$ & $L$ & NS \\
\hline Def + GA & $L$ & NS \\
\hline \multicolumn{3}{|c|}{ Urea comparisons ${ }^{x}$} \\
\hline Def versus Def $+U$ & NS & $* *$ \\
\hline Def 2500: Def + GA versus Def + GA $+U$ & * & NS \\
\hline Def5000: Def + GA versus Def + GA $+\mathrm{U}$ & NS & NS \\
\hline \multicolumn{3}{|c|}{ GA comparisons ${ }^{x}$} \\
\hline Def versus Def + GA & $*$ & NS \\
\hline Def $+U$ versus Def $+G A+U$ & NS & NS \\
\hline
\end{tabular}

${ }^{\mathrm{z} S p r a y}$ treatment combinations as outlined in Table 1 . Control $=$ sprayed with water; $\mathrm{U}=3 \%$ urea; GA $=$ $50 \mathrm{mg} \cdot \mathrm{L}^{-1}$ gibberellic acid from ProGibb T\&O; Def = 2500 (Def2500), 5000 (Def5000), 7500 (Def7500), and 10,000 (Def10000) $\mathrm{mg} \cdot \mathrm{L}^{-1}$ Def 6.

${ }^{\mathrm{y}}$ Means within a column denoted by asterisk(s) are significantly different from control plants $P<0.05(*)$, $P<0.01(* *)$, and $P<0.001(* * *)(\mathrm{n}=15)$.

${ }^{x}$ Def concentration responses: significant $(P<0.05)$ linear $(L)$ a priori polynomial contrasts based on the concentrations of Def in sprays. Urea comparisons and GA comparisons: specific a priori contrasts to assess the effect of adding urea and GA to sprays containing Def at $P<0.05(*), P<0.01(* *)$, and $P<0.001(* * *) ; \mathrm{NS}=$ nonsignificant $(P>0.05)$.

Results from Expt. 1 showed adding GA to lower concentrations of Def 6 sprays increased the efficiency of defoliation of florists' hydrangea and adding urea to Def 6 sprays improved plant performance during forcing and decreased the effectiveness of defoliation by Def 6. Based on these results, in Expt. 2, we sprayed plants with a combination of Def 6 , urea, and GA to determine whether the three compounds would act synergistically to improve both the effectiveness of defoliation (GA effects on Def 6) and plant performance during forcing (urea effects on Def 6). Adding urea to sprays containing $2500 \mathrm{mg} \cdot \mathrm{L}^{-1}$ Def 6 and GA decreased the effectiveness of Def 6 and GA on defoliation and adding urea to sprays containing $5000 \mathrm{mg} \cdot \mathrm{L}^{-1}$ Def 6 and GA had no influence on the defoliation effects of Def 6 and GA. Adding GA to sprays containing Def $6\left(5000 \mathrm{mg} \cdot \mathrm{L}^{-1}\right)$ and urea also had no influence on the defoliation effects of Def 6 and urea. Together, these results suggest that any synergism among these three compounds in a spray might be dependent on the concentration of the defoliant.
In conclusion, our results indicate Def 6 is an effective defoliant for use on florists' hydrangea at different times in the fall. Increasing the concentration of Def 6 from 2500 up to $10,000 \mathrm{mg} \cdot \mathrm{L}^{-1}$ can increase defoliation without visible injury to plants and adverse effects on suggest adding GA to lower concentrations of Def 6 sprays can improve defoliation activity of Def 6 and adding urea to Def 6 sprays has the potential to improve plant performance during forcing. The response of plants to defoliants is affected by many variables such as temperature, humidity and precipitation, species and cultivar, timing, chemical concentrations, soil moisture, nutrition, age of the plant, spray pressure and droplet size, adjuvant, water $\mathrm{pH}$, and so on (Larsen, 1973); therefore, it is important for hydrangea producers to conduct proper testing before adopting defoliation methods into production practices.

\section{Literature Cited}

Bailey, D.A. 1989. Hydrangea production. Timber Press, Portland, OR plant quality during forcing. Our results also
Bailey, D.A. 1990. Gibberellic acid enhances chemical defoliation of hydrangeas. HortScience 25:580.

Bi, G., C.F. Scagel, L. Cheng, and L.H. Fuchigami. 2005. Effects of copper, zinc and urea on defoliation and nitrogen reserves in nursery plants of almond. J. Hort. Sci. Biotechnol. 80:746-750.

Bi, G., C.F. Scagel, and R. Harkess. 2008. Rate of nitrogen fertigation during vegetative growth and spray applications of urea in the autumn alters growth and flowering of florists' hydrangeas. HortScience 43:472-477.

Chapin, F.S. and R.A. Kedrowski. 1983. Seasonal changes in nitrogen and phosphorus fractions and autumn retranslocation in evergreen and deciduous taiga trees. Ecology 64: 376-391.

Cheng, L., S. Dong, and L.H. Fuchigami. 2002. Urea uptake and nitrogen mobilization by apple leaves in relation to tree nitrogen status in autumn. J. Hort. Sci. Biotechnol. 77:13-18.

Cheng, L. and L.H. Fuchigami. 2002. Growth of young apple trees in relation to reserve nitrogen and carbohydrates. Tree Physiol. 22:12971303.

Cheng, L. and G. Xia. 2004. Growth and fruiting of young 'Concord' grapevines in relation to reserve nitrogen and carbohydrates. J. Amer. Soc. Hort. Sci. 129:660-666.

Guak, S., L. Cheng, and L.H. Fuchigami. 2001. Foliar urea pretreatment tempers inefficient $\mathrm{N}$ recovery resulting from copper chelate (CuEDTA) defoliation of apple nursery plants. J. Hort. Sci. Biotechnol. 76:35-39.

Knight, J.N. 1983. Chemical defoliation of nursery stock using chelated forms of copper and iron. J. Hort. Sci. 58:471-476.

Larsen, F.E. 1973. Promotion of leaf abscission in fruit nursery stock. Acta Hort. 34:129-133.

Larsen, F.E. and R. Fritts, Jr. 1986. Chemical defoliation of tree fruit nursery stock with CuEDTA. HortScience 21:281-283.

Sanchez, E.E., T.L. Righetti, D. Sugar, and P.B. Lombard. 1990. Response of 'Comice' pear tree to a postharvest urea spray. J. Hort. Sci. 65:541-546.

Shanks, J.B. 1969. Some effects and potential uses of ethrel on ornamental crops. HortScience 4:56-58.

Tagliavini, M., P. Millard, and M. Quartieri. 1998. Storage of foliar absorbed nitrogen and remobilization for spring growth in young nectarine (Prunus persica var. nectarina) trees. Tree Physiol. 18:203-207.

Taylor, B.K. 1967. Storage and mobilization of nitrogen in fruit trees. J. Austral. Inst. Agr. Sci. $33: 23-29$

Taylor, B.K. and L.H. May. 1967. The nitrogen nutrition of the peach tree. Aust. J. Biol. Sci. 20:389-411.

Titus, J.S. and S.M. Kang. 1982. Nitrogen metabolism, translocation, and recycling in apple trees. Hort. Rev. (Amer. Soc. Hort. Sci.) 4: 204-246.

Tjia, B. and J. Buxton. 1976. Influence of ethephon spray on defoliation and subsequent growth on Hydrangea macrophylla Thunb. HortScience 11:487-488. 